\title{
An overview: the potential role of agro forestry in enhancing carbon sequestration and reducing greenhouse gas emissions on agricultural lands
}

\begin{abstract}
Agricultural production systems face major challenges under climate change scenarios in terms of expected negative impacts on productivity and persistence of the crops. Greenhouse gases from agriculture continue to rise although not as fast as from other fossil fuel-based human activities. Windbreaks perform several ecosystems functions that improve the local and regional capacity of crop systems to increase yields and offer environmental services by minimizing the negative effects of extreme weather events. Agro forestry systems also represent an important means of mitigating greenhouse gas emissions. This is predominantly accomplished by the trees and crops storing carbon (C) in their above and belowground woody tissue while reducing carbon dioxide $\left(\mathrm{CO}_{2}\right)$ emissions either through avoidance of emissions or through energy savings. However, available and reliable data for estimating agro forestry contributions to whole-farm and regional $\mathrm{C}$ assessments are scarce and in most regions, do not exist. The main objective of this research was to analyze the $\mathrm{C}$ storage potential of agro forestry systems and to estimate the extent of potential reduction in emissions due to the presence of trees in different farming scenarios.
\end{abstract}

Volume 8 Issue 6 - 2018

\author{
William Ballesteros Possu, Jorge Fernando \\ Navia Estrada, Hector Ordoñez Jurado \\ Faculty of Agricultural Sciences, Universidad de Nariño, San Juan \\ de Pasto, Colombia
}

Correspondence: William Ballesteros Possu, Faculty of Agricultural Sciences, Universidad de Nariño, San Juan de Pasto, Suamtambo I bloque 7 Apt 502, San Juan de Pasto, Colombia,Tel (052)3154019339Email wballasterosp@gmail.com

Received: June 25, 2018 | Published: November 26, 2018

\section{Introduction}

Increasing levels of atmospheric greenhouse gases (GHGs) are triggering changes in our climate. In 2013, the Intergovernmental Panel on Climate Change ${ }^{1}$ reported new and stronger evidence confirming that most warming observed over the last 50years was attributable to anthropogenic causes. Climate change may impact society and ecosystems in a broad variety of ways. ${ }^{2,3}$ There are conflicting perspectives about how to deal with the extent of its negative impacts. Dealing with these impacts requires countries around the world to reduce their atmospheric GHG emissions, ${ }^{4}$ which in turn involves an enormous investment of capital and human resources, and a radical transformation of production systems and consumptive behavior. ${ }^{1,5}$ Decision makers are discussing strategies to reduce GHG emissions. However, some strategies are not well received, and nothing is agreed upon by all nations. ${ }^{6}$ In order to resolve this conflict, the world needs reliable tools to inform decision-makers, international negotiators, and public opinion about climate-change adaptation and mitigation management options.

Although the impact of the natural and anthropogenic perturbations on GHG emissions is permanent, future changes may be substantially reduced to safer levels. ${ }^{4,7}$ Personal lifestyle changes that reduce the use of fossil fuels and reinforce sustainable farming can help minimize our $\mathrm{C}$ footprint. The Climate Smart Agriculture Approach ${ }^{5}$ offers a set of practices to tackle atmospheric GHGs. Sustainable methods for managing GHGs in United States agricultural lands have been summarized in a CAST report (2011) and include: conservation, converting croplands to pasture, no till, reduced fuel use, forestation and reforestation. Agro forestry, the integration of woody plants into crops/livestock operations, is one of these methods. Since the Kyoto Protocol, agro forestry systems have gained more attention as a strategy to capture and store carbon $(\mathrm{C}){ }^{8,9} \mathrm{The} \mathrm{IPCC}^{10}$ reports that, "Agro forestry can both sequester $\mathrm{C}$ and produce a range of economic, environmental, and socioeconomic benefits." Consequently, integrating agro forestry onto the landscape is considered one of the best "no regrets" measures to help communities mitigate, adapt, and become resilient to the impacts of climate change. ${ }^{11}$
Despite agro forestry systems being recognized as a feasible tool to provide tangible and intangible goods and services while producing $\mathrm{C}$ services, ${ }^{12,13}$ many gaps need to be filled to increase our understanding on how to best manage agro forestry for these services. These gaps can be addressed by increasing comprehensive scientific knowledge, ${ }^{14}$ generating accurate and reliable data ${ }^{12,14,15}$ unifying methodological approaches, ${ }^{6,14}$ and evaluating their impacts on farming operations and $\mathrm{C}$ budgets. ${ }^{5,714}$ Climate change presents a planet-wide experiment for researchers. There are many interventions under investigation. Integrating agro forestry practices on cultivated lands to tackle GHG emissions is one of them. Sound agro forestry research is the first step to understanding the factors related to climate change and how they will enhance the carbon storage potential for agricultural systems.

\section{Carbon cycle}

The $\mathrm{C}$ cycle is the flux of $\mathrm{C}$ among the atmospheric, oceanic, terrestrial biosphere and geological deposits ${ }^{16,17}$ which is stored in "carbon pools" (C stocks or reservoirs). ${ }^{18-20}$ Within these pools, C flows from one source to another, transforming $\mathrm{C}$ from source to sink, and vice versa. ${ }^{21}$ According to the United Nations Framework Convention on Climate Change, "A [C] source is any process or activity that releases a greenhouse gas, an aerosol, or a precursor of a greenhouse gas into the atmosphere; whereas a sink is any process, activity, or mechanism which removes $\mathrm{C}$ from the atmosphere". Therefore, $\mathrm{C}$ sequestration is the capture and storage of $\mathrm{C}$ that would otherwise be emitted into the atmosphere. ${ }^{22,23}$ Concentrations of carbon dioxide $\left(\mathrm{CO}_{2}\right)$, a major cause of global warming, have increased at their fastest rate for the last 30years. ${ }^{24}$ The rise in $\mathrm{CO}_{2}$ availability directly impacts photosynthetic processes evoking a wide range of physiological and morphological responses in plants. ${ }^{25,26}$ It is believed that most woody plants can produced more biomass at an elevated $\mathrm{CO}_{2}$ concentration, ${ }^{27-33}$ however, many uncertainties remain about which tree species will benefit or be constrained at that concentration because the benefits of "growth" may be more appealing to pest or diseases. $^{34-36}$

Based on photosynthetic physiology, it is likely that the additional 
C uptake beyond a threshold will limit the plant's ability to effectively uptake $\mathrm{CO}_{2}{ }^{25}$ Additionally the capacity of surface waters to take up anthropogenic $\mathrm{CO}_{2}$ is decreasing as levels increase. These phenomena make concentrations of $\mathrm{CO}_{2}$ more sensitive to natural and anthropogenic emissions. ${ }^{1}$ Many uncertainties remain and more research is needed to define the effect of natural sinks in the further reduction of $\mathrm{CO}_{2}$. Given this situation, mitigation and adaptation strategies aimed to address these challenges are being proposed. Mitigation strategies tackle the causes of climate change and adaptation attacks the effects of the climate change on humans and ecosystems. ${ }^{4}$ Jacoby et al., ${ }^{37}$ define mitigation as actions that reduce human contributions of GHGs to the planet. IPCC ${ }^{4}$ states that adaptation is the process of adjustment to actual or expected climate and its effects. Mitigation measures include lowering emissions of GHGs $\left(\mathrm{CO}_{2}, \mathrm{NO}_{2}\right.$, and $\left.\mathrm{CH}_{4}\right)$ and increasing the net uptake of $\mathrm{CO}_{2}$ through land-use changes, like forestry. These environmental threats can be mitigated if excess $\mathrm{C}$ is removed from the atmosphere, but according to the National Climate Assessment. ${ }^{38}$ "Natural processes only remove roughly half of the current rate of emissions from human activities. Therefore, mitigation efforts that only stabilize global emissions will not reduce the overall atmospheric concentrations of $\mathrm{C}$, but will only limit the rate of the increase. The same is true for other long-lived greenhouse gases." All of these statements indicate that humans have a significant role to play in addressing climate change. Their intervention is needed to reduce GHG emissions to safer levels and to stabilize the $\mathrm{C}$ cycle through $\mathrm{C}$ storage.

\section{Direct carbon storage}

Direct $\mathrm{C}$ storage refers to a set of processes designed to capture $\mathrm{CO}_{2}$ from the atmosphere, and then store it in either woody material or in other more stable fractions, such as in soils or geological formations. ${ }^{9}$ $\mathrm{Lal}^{39}$ identified four direct $\mathrm{C}$ sinks:

i. Forestation, where $\mathrm{CO}_{2}$ is removed from the atmosphere via biological activity;

ii. Aquifer storage, where $\mathrm{CO}_{2}$ is injected into terrestrial aquifers and is trapped hydro-dynamically;

iii. deep-sea storage, where $\mathrm{CO}_{2}$ is injected into the ocean at approximately $3,000 \mathrm{~m}$., where it is believed to remain stable for the long term; and

iv. Mineral carbonation, in which the $\mathrm{CO}_{2}$ reacts with minerals to form solid carbonates.

The focus of this dissertation is on the first phenomenon, carbon storage by via plants. Here, direct plant $\mathrm{C}$ sequestration takes place when plants photosynthesize atmospheric $\mathrm{CO}_{2}$ and store it as plant biomass. Subsequently, in forestation (tree-based) activities some of this plant biomass is fixed in woody materials while other biomass is indirectly sequestered as soil organic carbon (SOC) during decomposition processes. ${ }^{40-42}$ The accumulation of $\mathrm{C}$ fixed through agronomic, forestry, and conservation practices ultimately leads to a net gain in $\mathrm{C}$ fixation in soils. ${ }^{41}$ Biological uptake and storage in woody plant material is one way to mitigate GHG emissions. ${ }^{8}$ In temperate zones, sustainable agriculture, reforestation, a forestation, and agro forestry systems (AFS) represent potential C sinks. ${ }^{14,41,43-46}$

\section{Avoided $\mathbf{C}$ emissions or indirect $\mathbf{C}$ storage}

Avoided or reduced emissions refer to the estimate of $\mathrm{C}$ equivalent emissions that could have been released if a particular activity or intervention had not been carried out. ${ }^{47-49}$ In agriculture, these avoided emissions result from the reduced use of energy for planting and growing a crop; producing and using fertilizers and pesticides, clearing roads of snow during winter, and heating and cooling homes. ${ }^{50}$ Any practice that reduces the amount of fossil fuel usage will result in avoided $\mathrm{CO}_{2}$ emissions. ${ }^{2}$ Emissions avoidance is the most effective $\mathrm{C}$ management strategy to achieve atmospheric $\mathrm{CO}_{2}$ stabilization and a subsequent decline of atmospheric $\mathrm{CO}_{2} \cdot{ }^{51}$ Energy efficiencies through reduced energy consumption, renewable energy use, cleaner energy production, and switching to fuels with lower carbon contents are current strategies to reduce $\mathrm{CO}_{2}$ emissions. ${ }^{3}$

Trees and wood waste are also being used as alternative sources of energy. Biomass from trees is suitable to produce heat, power, and transportation fuels. ${ }^{52}$ Net $\mathrm{CO}_{2}$ emissions from a unit of electricity generation from bio-energy are 10 to 20times lower than from fossil fuel based electricity generation. ${ }^{52}$ Incorporating trees into the farm system provides additional benefits. Field windbreaks result in fewer acres being farmed which means a reduction in fuel consumption and a reduction of $\mathrm{C}$ emissions ${ }^{43}$ Fewer acres farmed reduce fertilizer and pesticide inputs, thus reducing the off-farm carbon impact. ${ }^{43}$ Trees around buildings, rural and urban homes reduce the amount of fossil fuel required for heating and cooling. ${ }^{43,50,53-55}$ Depending on climatic zone; building size, structure and age; and the type of energy consumed protecting these structures can provide significant savings. ${ }^{43}$

\section{The role of agriculture in contributing to GHG production and mitigation}

Agriculture has been identified as one of the anthropogenic activities that produce substantial amounts of GHGs. ${ }^{56,57}$ Burning fossil fuels is the leading cause of anthropogenic GHG emissions into the atmosphere in the form of $\mathrm{CO}_{2} \cdot{ }^{58}$ Besides emitting $\mathrm{CO}_{2}$, the rate of methane $\left(\mathrm{CH}_{4}\right)$ emissions from farming operations has doubled over the last 25 years, increasing at a rate of $1 \%$ per year ${ }^{59}$ with $70-90 \%$ coming from biotic sources. ${ }^{60}$ Atmospheric concentrations of nitrous oxide $\left(\mathrm{N}_{2} \mathrm{O}\right)$ are reported to have increased from $270 \mathrm{ppb}$ during the preindustrial era to $325 \mathrm{ppb}$ in $2014 .^{2}$ At the global, regional, and local scale, agriculture is considered the largest source of anthropogenic $\mathrm{N}_{2} \mathrm{O}$ and $\mathrm{CH}_{4}{ }_{4},{ }^{61}$ contributing $52 \%$ of global methane and $84 \%$ of global nitrous oxide emissions. ${ }^{62}$ Agricultural systems continue to add $\mathrm{C}$ to the atmosphere by using fossil fuels in machinery, using chemicals and other inputs that are energy intensive to manufacture, and cultivating soil, which results in a dynamic release of C..$^{22,39,63} \mathrm{~A}$ global analysis of soil C loss following cultivation of forests or grasslands shows a $20 \%$ reduction of the initial soil organic carbon (SOC), or approximately $1,500 \mathrm{gm}^{-2}$ in the top $0.3 \mathrm{~m}$ of the soil. ${ }^{64}$ Davidson \& Ackerman ${ }^{65}$ estimated 30\% SOC loss within 20years following cultivation, with the greatest loss in the first 5years. Conversely, agriculture is also an accumulator of $\mathrm{C}$; offsetting loses when the organic matter (OM) accumulates in the soil or when aboveground woody biomass acts either as a semi-permanent sink or is used as an energy source. ${ }^{39,63,66-69}$

Long-term rates of $\mathrm{C}$ storage are reported in different agro ecosystems ranging from a low of $0.2 \mathrm{~g} \mathrm{C} \mathrm{m}^{-2} \mathrm{yr}^{-1}$ in some polar deserts to more than $10 \mathrm{~g} \mathrm{C} \mathrm{m}^{-2} \mathrm{yr}^{-1}$ in some forest ecosystems. ${ }^{70}$ Most agro ecosystems have the potential to store C. Pastures, agro forestry and forest ecosystems tend to lead in soil $\mathrm{C}$ storage, depending on the region. In some regions, large agricultural areas represent a considerable potential for enhancing the rate of $\mathrm{C}$ sequestration through management activities that reverse the effects of cultivation on soil organic carbon (SOC) pools. ${ }^{71}$ In these cases, refilling depleted soil C pools via woody biomass production may result in much higher rates of SOC storage than the accumulation of passive soil C 
as documented by Schlesinger. ${ }^{70}$ These results suggest that enhancing the transfer of atmospheric $\mathrm{C}$ into soil using specific soil management practices may help mitigate climate-change impacts. However, this concept only applies when the additional $\mathrm{C}$ remains stored and is not rapidly released. ${ }^{68,72}$ For this reason, it is essential to estimate the duration of storage or mean residence time (MRT) of C in agricultural soils. $^{73}$

\section{Building a climate smart agriculture}

Addressing the global challenges of climate change, food security, and poverty alleviation requires enhancing the adaptive capacity and mitigation potential of agricultural landscapes throughout the world. ${ }^{74}$ Agriculture must simultaneously address three interwoven challenges: food security, adaptation to climate change, and mitigation of climate-change impacts. ${ }^{5,75,76}$ The Climate Smart Agriculture (CSA) approach was proposed by $\mathrm{FAO}^{5}$ as a strategy to tackle these social and environmental challenges. Climate Smart Agriculture is defined as the integration of the three dimensions of sustainable development to address food security and climate challenges: social, economic, and environmental. ${ }^{5}$ Several management strategies hold particular promise for simultaneously achieving these three goals of production, adaptation and mitigation at the plot and farm scale. ${ }^{77}$ For example, soil conservation practices, such as conservation tillage can increase soil health and protect the soil from extreme weather events. ${ }^{78}$ Many "climate-smart" practices that address both adaptation and mitigation goals are already well-known and fall under the greater umbrella of conservation agriculture, agro forestry, sustainable agriculture, evergreen agriculture, silvo pastoral systems, sustainable land management, eco-agriculture, or best-management practices. ${ }^{5,79}$ Still, a greater understanding of these practices and their adoption rate is required to produce reliable information and technologies that land managers will embrace. ${ }^{77}$

\section{The role of agro forestry systems in the climate smart} agriculture approach

Agro forestry systems (AFS) are defined as technologies where woody perennials (trees, shrubs, palms, and bamboos) are deliberately grown on the same land-management units as agricultural crops and/or animals, in some form of spatial arrangement or temporal sequence. ${ }^{8,80}$ Integrating woody plants into crop and livestock systems, if properly designed and located, can improve soils, increase water and air quality, and enhance wildlife habitat, while at the same time supporting sustainable production. ${ }^{81}$ While agro forestry plays a significant role in mitigating the concentration of GHGs, it also helps farmers to adapt to climate change ${ }^{82,83}$ For these reasons, agro forestry is included as a management option for $\mathrm{C}$ sequestration under the Clean Development Mechanisms of the Kyoto Protocol ${ }^{19,84,85}$ and CSA approach. ${ }^{5}$ In North America, there are five main categories of agro forestry practiced: riparian forest buffers, windbreaks, alley cropping, silvo pasture, and forest farming. These categories vary according to the structure and function of their components. By incorporating agro forestry practices into agricultural operations, the amount of $C$ that can potentially be sequestered is greater than that achievable by crops alone. ${ }^{86,87}$ At a global scale this potential ranges from 0.29 to $15.21 \mathrm{Mg}$ $\mathrm{ha}^{-1} \mathrm{yr}^{-188}$ while conservation practices on croplands in the United States range from $0.1^{89}$ to $2.15 \mathrm{Mg} \mathrm{ha}^{-1} \mathrm{yr}^{-1} .^{90}$ The greatest dividend of $\mathrm{C}$ sequestered via agro forestry practices comes from the increased soil organic carbon (SOC) belowground and the woody biomass, above- and belowground. ${ }^{8,91}$
Although $\mathrm{C}$ sequestration through afforestation and reforestation has long been considered useful in climate-change mitigation, ${ }^{8}$ agro forestry offers distinct advantages. Agro forestry practices enhance the capability of farmers to increase soil health, improve air and water quality, increase local biodiversity, reduce weeds and pests, reduce pressure on natural forests, and enhance welfare for livestock. ${ }^{43,92-95}$ Likewise, these systems can enhance the resilience of farms coping with extreme events. ${ }^{82,83}$ Agro forestry, when used to intensify agriculture production, provides additional indirect benefits by: 1) reducing the farm's use of fossil fuels, 2) reducing the energy used for heating and cooling homes and other buildings, 3) reducing the inputs applied to crops and livestock, and 4) providing more diversity for wildlife habitat. ${ }^{43,63,96}$ Likewise, diversifying the crop production system to include a significant tree component may buffer the income risks associated with climatic variability. ${ }^{82}$

Globally, agro forestry offers important opportunities to create synergies between adaptation and mitigation actions. ${ }^{5}$ Simulation models developed to evaluate the potential of agro forestry practices to store $\mathrm{C}$ suggested that there are approximately 85 to $1,215 \mathrm{M}$ ha in agro forestry practices in Africa, Asia, and the Americas. ${ }^{97}$ The IPCC projected that $630 \mathrm{M}$ ha of unproductive cropland and grassland could be converted to agro forestry by $2010^{8}$ and could potentially sequester 1.43 and 2.15Tg $\mathrm{CO}_{2} \mathrm{yr}^{-1}$ by 2010 and 2040, respectively. Kumar et al., ${ }^{98}$ estimated that $1,023 \mathrm{M}$ ha are currently under agro forestry worldwide. The global potential to sequester $\mathrm{C}$ was estimated at 1.1 to $2.2 \mathrm{Gt}(1 \mathrm{Gt}=1,000 \mathrm{Tg})$ of $\mathrm{C}$ per year over 50 years. ${ }^{97} \mathrm{Using}$ values and total land area planted to agro forestry $\left(1,215 \mathrm{M}\right.$ ha) from Dixon $^{97}$ a $\mathrm{C}$ sequestration potential of $1.9 \times 10^{3} \mathrm{Tg} \mathrm{C}_{\mathrm{yr}}{ }^{-1}$ over 50years was calculated. ${ }^{99}$ These estimates are close to the 1.6 to $1.8 \times 10^{3} \mathrm{Tg} \mathrm{C} \mathrm{yr}^{-1}$ lost due to deforestation and other agricultural activities. ${ }^{100}$ However, in order to increase the amount of $\mathrm{C}$ sequestration and contribute effectively to atmospheric $\mathrm{CO}_{2}$ reduction, new agro forestry projects must be implemented on the remaining 3,953M ha of cropland and pastures in the world. ${ }^{99}$

In North America, potential C sequestration rates of AFS for aboveand belowground biomass components were estimated at $2.6 \mathrm{Mg} \mathrm{C}$ $\mathrm{ha}^{-1} \mathrm{yr}^{-1}$ for riparian forest buffers, $3.4 \mathrm{Mg} \mathrm{Cha}^{-1} \mathrm{yr}^{-1}$ for alley-cropping systems, $6.1 \mathrm{Mg} \mathrm{C} ~ h a^{-1} \mathrm{yr}^{-1}$ for silvo pastures, and $6.4 \mathrm{Mg} \mathrm{C}^{-1} \mathrm{yr}^{-1}$ for windbreaks. ${ }^{6}$ Additionally, $630 \mathrm{M}$ ha of unproductive croplands and grasslands could be converted to agro forestry, representing a $\mathrm{C}$ sequestration potential of $0.4 \mathrm{Tg} \mathrm{C} \mathrm{yr}^{-1}$ by 2010 and $0.6 \mathrm{Tg} \mathrm{C} \mathrm{yr}^{-1}$ by $2040 .{ }^{19,101}$ These estimates were derived from $1.69 \mathrm{M}$ ha under riparian buffers, $17.9 \mathrm{M}$ ha (10\% of total cropland) in alley cropping, and $78 \mathrm{M}$ ha of silvopasture $(23.7 \mathrm{M}$ ha or $10 \%$ of pasture land, and $54 \mathrm{M}$ ha of grazed forests). ${ }^{6,14}$ These systems have the potential to store 4.7, 60.9, 474 and 8.79 to $58 \mathrm{Tg} \mathrm{C} \mathrm{yr}^{-1}$, respectively. ${ }^{6}$ Estimates of the $\mathrm{C}$ storage potential for agro forestry systems are shown in Table 1 . Although there is little doubt about the potential of agro forestry to store $\mathrm{C}$, their effectiveness is determined by local physical, ecological, and socioeconomic factors..$^{14,102}$ Locally, the amount of $\mathrm{C}$ in any agro forestry system depends on the structure and function of different components within the specific system. ${ }^{103,104}$ The interaction among these factors generates high levels of spatial heterogeneity among similar agro forestry practices at different locations. ${ }^{91}$ Therefore, extrapolation across systems and locations can be misleading when applying local results on a global scale. ${ }^{91,105,106}$

As with all agricultural management activities, agro forestry systems can function as both a source and sink of GHG. ${ }^{6,15,91,97}$ Evidence from Dixon ${ }^{97}$ Chikowo et al. ${ }^{107}$ Kandji et al. ${ }^{108}$ suggests that the type 
of agro forestry system greatly influences whether the components function as a source or sink and to what extent. For instance, Dixon ${ }^{97}$ Chikowo et al., ${ }^{107}$ Kandji et al., ${ }^{108}$ show improved fallows and silvo pastures as sources of $\mathrm{NO}_{2}$ and $\mathrm{CH}_{4}$, respectively. However, the net $\mathrm{C}$ equivalent in the aboveground and belowground biomass of an agro forestry system is generally much higher than the equivalent land use without trees ${ }^{12,44,94,109}$ see Table 1 . In the case of riparian forest buffers in agricultural systems, these plantings can reduce excess $\mathrm{NO}_{2}$ emissions through the uptake of $\mathrm{N}$ by trees. ${ }^{110}$ reduce the impacts from flood events, ${ }^{111}$ store $\mathrm{C}$, prevent nutrient losses, and reduce erosion. ${ }^{112}$ Similarly, planting bio fuel crops on arable lands can potentially reduce nitrate losses ${ }^{113}$ and soil erosion. ${ }^{114,115}$ Incorporating a bio feed stock component into riparian buffer systems, where appropriate, can provide farmers with additional income as well as provide added GHG mitigation and water quality services. ${ }^{83}$ Inventory data and field measurements of agro forestry within the US, and more broadly North America, are very limited. ${ }^{116}$ Carbon sequestration estimates reported above were made using a variety of broad assumptions. The inherent variability of $\mathrm{C}$ storage potential and the lack of uniform methodologies among the many estimates make statistical comparisons challenging. ${ }^{101,109}$ Despite these difficulties, trends from the information at hand indicate that $\mathrm{AFS}$ will sequester $\mathrm{C}$ and favorably reduce $\mathrm{CO}_{2}$ emissions. ${ }^{12,13,15,106,117}$

Table I Worldwide carbon storage potential of agro forestry systems

\begin{tabular}{|c|c|c|c|}
\hline Agroforestry/land-use system & Years & $\begin{array}{l}\text { Carbon storage } \\
\left(\mathbf{M g ~ h a}^{-1} \mathrm{yr}^{\prime}\right)\end{array}$ & Source \\
\hline Fodder bank, Segou (MaliW African Sahel) & 7.9 & 0.3 & Takimoto et al., ${ }^{187}$ \\
\hline Live fence, Segou (Mali,W African Sahel) & - & 0.6 & Takimoto et al., ${ }^{187}$ \\
\hline Tree-based intercropping (Canada) & 13.0 & 0.8 & Peichl et al., ${ }^{188}$ \\
\hline Parklands, Segou, Mali (W African Sahel) & 35.0 & I.I & Takimoto et al., ${ }^{187}$ \\
\hline Agrisiliviculture (Chattisgarh, central India) & 5 & 1.3 & Swamy \& Puri'189 \\
\hline Silvopasture (W Oregon, USA) & 11 & I.I & Sharrow \& Ismail ${ }^{190}$ \\
\hline Cacao agroforests (Mokoe, Cameroon) & 26 & 5.9 & Duguma et al., ${ }^{191}$ \\
\hline Cacao agroforests (Turrialba, Costa Rica) & 5 & 10.3 & Beer et al., ${ }^{192}$ \\
\hline Cacao agroforests (Turrialba, Costa Rica) & 10 & 11.1 & Beer et al.., ${ }^{192}$ \\
\hline Shaded coffee (SW Togo) & 13 & 6.3 & Dossa et al., ${ }^{193}$ \\
\hline Agroforestry woodlots (Kerala, India) & 5 & 6.6 & Kumar et al.., ${ }^{194}$ \\
\hline Home and outfield gardens & 23.2 & 4.3 & Kirby \& Polvin 195 \\
\hline Indonesian home gardens, (Sumatra) & 13.4 & 8.0 & Roshetko et al., ${ }^{196}$ \\
\hline Mixed species stands, (Puerto Rico) & - & 621 & Parrotta ${ }^{197}$ \\
\hline Agroforestry systems (world) & 50 & 1.7 & $\mathrm{IPCC}^{22}$ \\
\hline Agroforestry systems (World) & 50 & 1.9 & Dixon et al., ${ }^{97}$ \\
\hline Agroforestry systems (world) & - & 0.7 & Eagle et al., ${ }^{15}$ \\
\hline Agroforestry systems (world) & - & $0.2-4.6$ & $\begin{array}{l}\text { Krankina \& Dixon }{ }^{198} \\
\text { Schroeder }{ }^{103} \text { Winjum et al., }{ }^{199} \\
\text { Pandey }\end{array}$ \\
\hline Agroforestry slow growing trees (Europe) & - & $0.1-0.57$ & Palma et al., ${ }^{201}$ \\
\hline $\begin{array}{l}\text { Agroforestry mod. fast growing trees } \\
\text { (Europe) }\end{array}$ & - & $0.54-0.9$ & Palma et al., ${ }^{201}$ \\
\hline Agroforestry fast growing trees (Europe) & - & $2.1-3.0$ & Palma et al., ${ }^{201}$ \\
\hline Agroforestry systems (tropical) & - & $1.5-3.5$ & $\begin{array}{l}\text { Montagnini \& Nair' Watson } \\
\text { et al., }{ }^{84}\end{array}$ \\
\hline Agroforestry systems (tropical) & - & $3.1-4.3$ & Beer ${ }^{192}$ \\
\hline Agroforestry (USA) & - & $0.22-1.88$ & Eagle et al.,.15 \\
\hline Riparian buffer/mile (USA) & 40 & $5.01-10.03$ & Schoeneberger ${ }^{12}$ \\
\hline Riparian buffer/mile (USA) & - & 1.8 & Hazlett et al.,. ${ }^{202}$ \\
\hline Riparian buffer (USA) & & 1.87 & Nair \& Nair ${ }^{14}$ \\
\hline Riparian buffer/mile (USA) & - & 4.8 & Rheinhardt et al., ${ }^{203}$ \\
\hline Agroforestry (USA) & & 0.72 & Dixon et al..$^{97}$ \\
\hline
\end{tabular}


Table Continued

\begin{tabular}{llll}
\hline Agroforestry/land-use system & Years & $\begin{array}{l}\text { Carbon storage } \\
\left(\mathbf{M g ~ h a}^{-1} \mathbf{y r}^{\prime}\right)\end{array}$ & Source \\
\hline Alley cropping (USA) & - & $2.4-3.4$ & Udawatta \& Jose $^{6}$ \\
Alley cropping (USA) & - & 4.5 & Nair \& Nair \\
Alley cropping (USA) & 1.15 & Nair \& Nair \\
Alley cropping (USA) & - & 1.15 & Lal et al., $^{89}$ \\
Alley cropping (USA) & - & $0.5-13.2$ & Bambrick $^{204}$ \\
Silvopasture (USA) & - & 5.1 & Udawatta \& Jose $^{6}$ \\
Silvopasture (USA) & - & 0.3 & USDA-NAC $^{148}$ \\
Silvopasture (USA) & - & 2.6 & Nair \& Nair \\
Silvopasture (USA) & & & Nair \& Nair \\
\hline
\end{tabular}

\section{Source adapted from Nair et al., ${ }^{86}$}

As one of several promising climate-change mitigation and adaptation tools that will be needed for agricultural lands under the uncertainty of climate change ${ }^{7}$ implementing agro forestry projects is justified for many reasons. First, an increase in soil C significantly benefits agricultural productivity and sustainability. ${ }^{82,86,118-120}$ Second, it is improbable that any single mitigation method can achieve $\mathrm{CO}_{2}$ reduction targets, rather combining several management activities, including the perennial-based agro forestry practices, appears to be a more realistic way to achieve $\mathrm{CO}_{2}$ reduction targets, especially under the uncertainties of climate change. ${ }^{106,121}$ Third, as the sale of $\mathrm{C}$ through Clean Development Mechanisms (CDM) becomes more popular in the future, agro forestry systems will definitely have potential to provide economic revenue for farmers while working to improve the environment, especially in developing countries. ${ }^{122}$ Integrated analysis of agro forestry shows that these systems can sequester $\mathrm{C}$ and potentially increase incomes of farmers around the world. ${ }^{123}$

\section{Windbreaks/shelterbelts}

Temperate agro forestry systems in North America encompass five categories of practices as cited in Table $1 .{ }^{124}$ Windbreaks (also referred to as shelterbelts) are particularly attractive as a GHG mitigation tool for $\mathrm{C}$ storage in agricultural lands. ${ }^{12}$ This is because windbreaks take only a small portion of land out of production (3-5\%), ${ }^{124}$ yet provide many other services that are valued by the landowner and society, such as enhanced production to make up for the land taken out of production, along with the co-benefits of $\mathrm{C}$ sequestration and avoided emissions. ${ }^{12}$ Windbreaks are linear arrays of trees and shrubs ${ }^{125}$ that serve as barriers to reduce wind speed. ${ }^{124,126}$ They usually consist of one or more rows of trees or shrubs planted on croplands or grazing lands to alter the local microclimate ${ }^{124,127}$ protect crops and livestock, ${ }^{124}$ provide habitat for wildlife ${ }^{128,129}$ and mitigate odors from farming operations. ${ }^{130}$ Windbreaks reduce evapotranspiration ${ }^{124,131}$ wind erosion, and soil detachment by rain drops ${ }^{43}$ They supply additional $\mathrm{C}$ sequestration in crop and livestock production systems, and increase energy savings in farm operations by reducing the amount of fossil fuel required to heat and cool homesteads and barns. ${ }^{43,52}$ Table 2 presents a review of studies that include a range of experimental designs, building types, landscaping, and climate conditions where energy savings for space heating and cooling ranged from $8 \%^{53}$ to $50 \% .^{54}$

Conservative energy savings ranging from 10 to $25 \%$ reported by $\mathrm{USDA}^{132}$ need to be re-evaluated due to the technological advances in heating and cooling systems, home insulation, appliance types, and the concerns about climate change. This value, however, is close to the estimate of Moyer ${ }^{133}$ in Saskatchewan (Canada). Other studies have examined urban tree plantings and found similar ranges in cooling savings from well-placed trees ranging from 10 to $43 \%{ }^{134}$ Living snow fences are windbreaks planted to manage drifting snow. Depending on the design, living snow fences can reduce snow removal costs from adjacent roadways and improve road safety by trapping snow close to the shelterbelt ${ }^{135-138}$ or provide critical spring soil moisture for crops during the growing season by distributing snow relatively uniformly across a field. ${ }^{139}$ Incorrectly designed and placed windbreaks, on the other hand, can cause snowdrifts that can bury livestock during major storms. ${ }^{140}$ There are many reviews of windbreak performance in different scenarios around the world and the reader is referred to these for specific details on the functions of windbreaks. . $^{6,15,43,131,141-146}$ Windbreaks have the most impact in semiarid areas where a major function is to protect soils from wind erosion. ${ }^{143}$ The largest and most extensive shelterbelt-planting program in United States history was "the Prairie States Forestry Project." In an effort to control the dust bowl the Federal Government initiated the planting of nearly $30,000 \mathrm{~km}$ of shelterbelts in six Great Plains States between 1935 and $1942 .{ }^{147}$ Today, the growth and vigor of many of these trees have declined due to lack of management, spacing, aging, and invasion of undesirable, short-lived trees. Many others have been removed to accommodate various types of irrigation systems particularly center pivot systems. As climate change concerns continue to rise, especially in regards to frequency and intensity of droughts, there is a renewed interest in windbreaks as both protection against wind erosion and as potential $\mathrm{C}$ sinks. Estimates of $\mathrm{C}$ sequestration by windbreaks are shown in Table 3. Most of these estimates are based only on the aboveground potion for different shelterbelt types in the United States and Canada. These estimates ranged from $0.68 \mathrm{Mg} \mathrm{C} \mathrm{km}^{-1}$ for singlerow shrubs ${ }^{43}$ to $105 \mathrm{Mg} \mathrm{C} \mathrm{km}^{-1}$ for single row hybrid poplar (Populus deltoides x Populus nigra Bartr. Ex. Marsh). ${ }^{55}$

Windbreaks contribute to the SOC pool, although at a limited spatial scale of the landscape. ${ }^{6}$ Sauer et al., ${ }^{105}$ reported SOC concentrations under a Nebraska shelterbelt to be $55 \%$ more than that in the adjacent crop field. The shelterbelt treatment contained $12 \%$ more SOC in the $7.5-15 \mathrm{~cm}$ depth compared to the crop field. Overall, during a 35 -year period, soils at $0-15 \mathrm{~cm}$ depth contained $3.71 \mathrm{Mg}$ more SOC ha-1 in the shelterbelt area than the cultivated zone, which according to Udawatta \& $\mathrm{Jose}^{6}$ can represent an annual sequestration 
of $0.11 \mathrm{Mg} \mathrm{ha}^{-1}$. Hernadez \& Ramirez ${ }^{119}$ indicated that a forestation of cropland carried out through either shelterbelt or forest plantation caused substantial increases in SOC accrual $(\geq 57 \%)$ in surface soil layers (to 7.5 or $10 \mathrm{~cm}$ deep) relative to conventionally, tilled cropping systems.

Table 2 Effects of windbreaks on energy savings in the United States and Canada

\begin{tabular}{|c|c|c|c|c|}
\hline House type & Place & $\begin{array}{l}\text { Energy } \\
\text { demand } \\
K w h^{-1}\end{array}$ & Energy savings(\%) & Author \\
\hline Heavily shaded house & Sacramento & $0.61-4.8$ & $25-50$ & Akbari et al.., ${ }^{54}$ \\
\hline Houses with air conditioner & Phoenix & 0.17 & 17 & Clark \& Berry 205 \\
\hline $\begin{array}{l}\text { Houses with air conditioners and } \\
\text { evaporative coolers }\end{array}$ & Phoenix & 0.35 & 14 & Clark \& Berry ${ }^{205}$ \\
\hline House without trees & & 3.55 & - & Clark \& Berry ${ }^{205}$ \\
\hline Simulation for Cities & U.S. & $0.15-0.5$ & $2-10$ & $\begin{array}{l}\text { Heisler, }{ }^{206} \text { Huang et al.., } \\
\text { McPherson } \\
{ }^{134,208}\end{array}$ \\
\hline Average House & Great Plains & - & $23-25$ & Bates $^{209}$ \\
\hline Average House & U.S. & - & 27 & USDA-NRCS ${ }^{132}$ \\
\hline Average House & Kansas & - & 15 & Woodruff 210 \\
\hline $\begin{array}{l}\text { Average House, single row } \\
\text { windbreak }\end{array}$ & & - & 40 & Mattingly $y^{53}$ \\
\hline Air conditioning reduction & New Jersey & - & 8 & Mattingly et al.,.53 \\
\hline Heating & New Jersey & - & 3 & Mattingly et al., ${ }^{53}$ \\
\hline Air conditioning reduction & New Jersey & - & 10 & Harrje et al. ${ }^{211}$ \\
\hline Heating energy & New Jersey & - & 3 & Harrje et al.,211 \\
\hline Heating energy & Pennsylvania & - & 12 & DeWalle \& Heisler ${ }^{50}$ \\
\hline Heating & Pennsylvania & - & 0 & Walk et al.., ${ }^{212}$ \\
\hline Typical northern US farm & & - & $10-30$ & DeWalle \& Heisler ${ }^{50}$ \\
\hline Wind speed reduction & Canada & - & $17-25$ & Moyer ${ }^{133}$ \\
\hline Urban home cooling & & - & $10-43$ & McPherson ${ }^{134}$ \\
\hline
\end{tabular}

Table 3 Estimates of carbon storage potential for windbreaks/shelterbelts

\begin{tabular}{|c|c|c|c|c|}
\hline Agroforestry/land-use system & Years & $\begin{array}{l}\text { Carbon storage } \\
\text { Mg }\end{array}$ & $\begin{array}{l}\text { Carbon } \\
\text { storage } \\
\mathrm{Mg} \mathrm{km}^{-1}\end{array}$ & Source \\
\hline Aboveground deciduous trees (Canada) & - & $0.11-0.367$ & 105 & Kort \& Turnock ${ }^{55}$ \\
\hline Aboveground coniferous trees (Canada) & - & $0.11-0.19$ & 24- 41 & Kort \& Turnock ${ }^{55}$ \\
\hline Aboveground shrub (Canada) & - & - & 11 & Kort \&Turnock ${ }^{55}$ \\
\hline Green ash (Canada) & 53 & 0.161 .8 & 32 & Kort \&Turnock ${ }^{55}$ \\
\hline Austrian pine (U.S.) & I & 0.004 & - & Sampson \& Kamp ${ }^{213}$ \\
\hline Eastern red cedar(U.S.) & I & 0.0015 & - & Sampson \& Kamp ${ }^{213}$ \\
\hline Manitoba maple (Canada) & 52 & 0.178 .6 & 34 & Kort \& Turnock ${ }^{55}$ \\
\hline Hybrid poplar (Canada) & 33 & 0.544 .3 & 105 & Kort \& Turnock ${ }^{55}$ \\
\hline Hybrid poplar (Canada) & 13 & 0.12 & - & Peichl et al., ${ }^{188}$ \\
\hline Hybrid poplar/tree/roots (Canada) & 12 & 0.02 & - & Gordon \& Thevathasan ${ }^{96}$ \\
\hline Poplar (Canada) & 25 & 0.03 & - & Wotherspoon et al.,.14 \\
\hline Red oak (Canada) & 25 & 0.03 & - & Wotherspoon et al.., ${ }^{214}$ \\
\hline Walnut (Canada) & 25 & 0.023 & - & Wotherspoon et al.,214 \\
\hline
\end{tabular}




\begin{tabular}{|c|c|c|c|c|}
\hline Agroforestry/land-use system & Years & $\begin{array}{l}\text { Carbon storage } \\
\text { Mg }\end{array}$ & $\begin{array}{l}\text { Carbon } \\
\text { storage } \\
\mathbf{M g ~ k m}^{-1}\end{array}$ & Source \\
\hline Norway spruce (Canada) & 25 & 0.03 & - & Wotherspoon et al., ${ }^{214}$ \\
\hline White cedar (Canada) & 25 & 0.02 & - & Wotherspoon et al.,214 \\
\hline Siberian elm (Canada) & 37 & 0.201 .9 & 40 & Kort \& Turnock ${ }^{55}$ \\
\hline White spruce (Canada) & 54 & 0.286 .9 & 41 & Kort \& Turnock ${ }^{55}$ \\
\hline Scots pine (Canada) & 66 & 0.164 & 24 & Kort \& Turnock ${ }^{55}$ \\
\hline Colorado spruce (Canada) & 43 & 0.202 & 29 & Kort \& Turnock ${ }^{55}$ \\
\hline Choke cherry (Canada) & 33 & 0.403 & 20 & Kort \& Turnock ${ }^{55}$ \\
\hline Villosa lilac (Canada) & 23 & 0.335 & 17 & Kort \&Turnock ${ }^{55}$ \\
\hline Buffalo berry (Canada) & 20 & 0.312 & 15 & Kort \& Turnock ${ }^{55}$ \\
\hline $\begin{array}{l}\text { Above-ground single row conifer } \\
\text { (Nebraska-USA) }\end{array}$ & 20 & - & 9.14 & Brandle et al.., ${ }^{43}$ \\
\hline Caragana (Canada) & 49 & 0.516 & 26 & Kort \& Turnock ${ }^{55}$ \\
\hline Sea buckthorn (Canada) & 25 & 0.213 & 11 & Kort \& Turnock ${ }^{55}$ \\
\hline $\begin{array}{l}\text { Aboveground single row deciduous } \\
\text { (Nebraska-USA) }\end{array}$ & 20 & - & $5.4 I$ & Brandle et al.., ${ }^{43}$ \\
\hline $\begin{array}{l}\text { Aboveground single row shrub conifer } \\
\text { (Nebraska-U.S.) }\end{array}$ & 20 & - & 0.68 & Brandle et al.., ${ }^{43}$ \\
\hline Hybrid poplar (Canada)/km & - & - & 105 & Kort \& Turnock ${ }^{55}$ \\
\hline Sea buckthorn/km & - & - & 11 & Kort \& Turnock ${ }^{55}$ \\
\hline Conifer & - & - & $24-.41$ & Kort\& Turnock ${ }^{55}$ \\
\hline Green ash & - & - & 0.32 & Kort \& Turnock ${ }^{55}$ \\
\hline $\begin{array}{l}\text { Two rows shelterbelt soil organic carbon } \\
15 \mathrm{~cm} \text { depth (Nebraska U.S.)/ha }\end{array}$ & 35 & 39.94 & - & Sauer et al., ${ }^{105}$ \\
\hline $\begin{array}{l}\text { Hypothetic windbreak Sounders, } \\
\text { Nebraska/ha }\end{array}$ & & 2.95 & - & Schoeneberger ${ }^{184}$ \\
\hline Soil organic Carbon 0 to $0.075 \mathrm{~m} / \mathrm{ha}$ & 36 & 23.1 & - & Brandle et al., ${ }^{124}$ \\
\hline Soil organic Carbon 0.075 to $0.15 \mathrm{~m} / \mathrm{ha}$ & 36 & 16.8 & - & Brandle et al.., ${ }^{124}$ \\
\hline
\end{tabular}

This increase of SOC in the shelterbelt is attributed to the absence of soil disturbance, increased litter accumulation, reduced erosion, and deposition of windblown material. ${ }^{107}$ Further research is needed to identify the mechanism (s) responsible for the observed patterns of SOC within and adjacent to the shelterbelt, and to quantify the $\mathrm{C}$ in biomass and deeper soil layers. ${ }^{107}$ Overall, the estimated C storage potential of different scenarios of windbreaks in the United States ranges from 2.9 to $11 \mathrm{Tg} \mathrm{C}$ ha $\mathrm{yr}^{-1}{ }^{6,14,43,91,148}$ According to the scientific body of research on agro forestry, windbreaks are a practical way to store $\mathrm{C}$ on agricultural lands, but many questions remain. As pointed out by Schoeneberger et al., ${ }^{83}$ the spatial and temporal dynamics in the system require additional research and technology investment. Few papers have been written about $\mathrm{C}$ stocks in trees on cultivated lands. ${ }^{105}$ Windbreaks lack explicit inclusion in any national inventory ${ }^{116}$ making it difficult to accurately estimate the land area occupied by this practice and therefore its $\mathrm{C}$ storage potential.

\section{Moving farming systems towards carbon neutral farming}

Integrated farming systems (or integrated agriculture) refer to agricultural systems that incorporate crops, domestic animals, trees, and non-conventional farming operations through nutrient cycling. ${ }^{149-153}$ The farm is conceived as a holistic or multi-functional land unit planned to maximize farm production and increase welfare of farm families ${ }^{150,152}$ while at the same time improving the environment. Integrating crops, livestock, and trees on farming operations is an agronomic, economic, and environmental challenge because of the complex interactions between components. ${ }^{154}$ Under holistic management, these types of production systems can achieve a more favorable net $\mathrm{C}$ footprint through crop residues, animal manures, soil conservation practices, crop rotations using intercropping and cover crops, and composting techniques. ${ }^{155}$ Studies in the United States show that alternative farming systems can achieve net returns comparable to those of conventional farms. ${ }^{156-158}$ While yields are usually somewhat lower, alternative farms often compensate by lower input costs and greater net returns. ${ }^{156,157,159}$ Studies comparing organic and conventional grain production systems show organic farming to be more sustainable. ${ }^{156,157,159-168}$

Soil tillage, planting, and harvesting operations account for the greatest expenditure of fuel, labor, and input costs. ${ }^{169}$ Approaches to decrease these expenses are reduced soil tillage, ${ }^{170}$ optimized fertilizer utilization and use efficiency, ${ }^{171}$ improved irrigation techniques, and 
enhanced solar drying. Likewise, considerable energy savings can come from intensive animal husbandry. ${ }^{1,172}$ Cole et al., ${ }^{171}$ Paustian et al., ${ }^{121}$ optimistically concluded that by integrating all of these possibilities, a 10 to $40 \%$ reduction in the current agricultural energy requirements might be achieved. Accordingly, theoretical U.S. fuel savings could be 0.01 to $0.05 \mathrm{Gt}$ Cyear. ${ }^{121}$ When trees are planted as agro forestry plantings on farms, the net GHG emissions in terms of $\mathrm{C}$ equivalents (CE) are substantially reduced. For a hypothetical farm of 250ha, in Nebraska, the $\mathrm{CO}_{2}$ sequestered under two management options (no-till with and without windbreaks) were estimate after 50years to be $9.2 \mathrm{Gt}$ under just no-till and $16.1 \mathrm{Gt}$ under no-till with 5\% of the land in windbreaks (the level of windbreaks generally prescribed for providing a good level of crop services). ${ }^{12}$ Farming systems that include agro forestry create more complex and productive units. Choosing a set of best practices involves more than simply identifying practices to reduce emissions or those that make immediate economic sense. A more holistic farming approach includes: finding ways to understand and quantify the diverse services provided to farms by windbreaks, developing new ways to better quantify $\mathrm{C}$ balance on farms, and improving methods to compare practices on the basis of emissions per unit of output, rather than merely based on emissions by unit of area. Many methods and tools are needed.

Estimating the amount of emissions and potential of $\mathrm{C}$ storage on integrated farms is a challenging task and research in this field is still in its early stages. However, some advanced decision-support tools can facilitate research and reduce the investigation time. The combination of these tools and other data from different sources can play an important role in furthering the understanding necessary to conduct more comprehensive agro forestry research. Denef et al., ${ }^{173}$ have reported on several science-based methods for quantifying GHG sources and sinks in agriculture and forestry. Decision-support tools to easily and accurately assess potential $\mathrm{C}$ contributions of agro forestry practices on farms are: Soil Changes under Agro forestry (SCUAF), ${ }^{174}$ COMET-VR 2.0, ${ }^{175}$ USAID FCC: Agro forestry tool, ${ }^{176}$ Integrated Farming Systems (IFSM), ${ }^{177}$ COMET-Farm, ${ }^{178}$ and HOLOS. ${ }^{179}$ Currently, some of these tools enable users to estimate C storage on farms with and without agro forestry systems, although these estimates are not without issue regarding accuracy.

COMET-Farm (http://cometfarm.nrel.colostate.edu/) is currently an entity-level, user-friendly tool for estimating the amount of $\mathrm{C}$ stored on agro forestry farms in the United States. This program places a value on a farm's C storage and under alternative management scenarios, including agro forestry. Amounts are then reported regarding GHG emissions between current management and future scenarios. ${ }^{178}$ HOLOS (www.agr.gc.ca/holos-ghg) estimates whole-farm GHG emissions and carbon storage from lineal tree plantings. And finally, another user-friendly tool for estimating GHGs is IFSM (http://www. ars.usda.gov/services/software/download.htm?softwareid=5) which includes livestock, but it does not include agro forestry practices. Overall, there is a high potential for windbreaks to help farm operations tackle the negative effects of climate change. Windbreaks can enhance the ability of farmers and agro ecologists to deal with the uncertainties of a changing climate. To achieve these goals, cropping systems, tree species, management regimes, weather and soils may be effectively exploited if managers have the information and tools to wisely design their production systems. The first step is to develop farm-level analyses of potential windbreak scenarios that will tackle the social and environmental challenges of climate-change mitigation and adaptation based on the pillars of Climate Smart Agriculture.

\section{Research needs}

According to Nair et al., ${ }^{13}$ agro forestry has come of age during the past three decades. The amount of scientific data has expanded, yet the understanding of $\mathrm{C}$ storage and dynamics in AFS is still minimal. Similarly, a comprehensive study of the C storage potential of AFS on the North American continent is lacking in the literature. ${ }^{180}$ More research is necessary to more fully understand the performance of agro forestry as a GHG source or sink. The required inquiries include:

i. Evaluating the emission and capture of nitrous oxides and methane, ${ }^{13}$ developing standardized methodologies for estimating and reporting above- and belowground $\mathrm{C}$ stocks; ${ }^{181}$

ii. Including $\mathrm{C}$ stored by agro forestry practices which are often left out in the current estimates; ${ }^{104}$

iii. Analyzing soil C storage in layers deeper than $0.2 \mathrm{~m} ;{ }^{87,106}$

iv. Developing predictive models to simulate future climate and agro forestry systems ${ }^{44}$

v. Assessing the dynamics of pests and diseases in agro forestry systems and developing more powerful methods to financially assess agro forestry practices; ${ }^{122}$

vi. Developing accurate biomass equations to reliably estimate the C storage potential of agro forestry systems; $;{ }^{182}$

vii. Generating a wide range of agro forestry tree species for present and forthcoming climates;

viii. Developing decision-support tools and models. ${ }^{83,183}$

From this list, one particular research need stands out - that accounting protocols and methodologies need to be developed for estimating $\mathrm{C}$ benefits from agro forestry plantings, especially at regional and national scales. ${ }^{184}$ Agroforestry-specific equations are very limited, ${ }^{6,55,109,185}$ because there is a lack of the regional and U.S.wide data sets required for developing agro forestry-specific models that go into making $\mathrm{C}$ estimates. ${ }^{182}$ Compared to forests, agro forestry plantings have a more open environment, resulting in trees with greater branch production and specific gravity. ${ }^{186}$ These differences indicate that existing forest-derived equations may not accurately estimate tree biomass. ${ }^{186}$

In summary, current understanding of $\mathrm{C}$ capture and storage by agro forestry is limited and many uncertainties remain about the level of their impact on $\mathrm{C}$ budgets. Wide ranging data on agro forestry practices are not available to estimate accurate levels of direct and indirect $\mathrm{C}$ sequestration in the United States. ${ }^{15}$ More comprehensive research, information decision-support tools and models need to be developed. ${ }^{183}$ Although work remains regarding the research potential of agro forestry for North American agriculture, we need to be finding ways to use the science at-hand to assist those formulating land management decisions now. ${ }^{83,215-219}$

\section{Acknowledgments}

None.

\section{Conflicts of interest}

Author declares that there is no conflicts of interest. 


\section{References}

1. The physical science basis. Working group I contribution to the IPCC fifth assessment report. Geneva: IPCC; 2013.

2. U.S. Environmental Protection Agency (USEPA). Climate change impacts and adapting to change. 2014.

3. U.S. Environmental Protection Agency (USEPA). Overview of Greenhouse Gases: Emissions of fluorinated gases. 2016.

4. Climate change 2014 synthesis report summary for policymakers. Geneva: IPCC; 2014.

5. Food and Agriculture Organization of the United Nations. "ClimateSmart" Agriculture policies, practices and financing for food security, adaptation and mitigation. FAO. 2010.

6. Udawatta RP, Jose S. Carbon sequestration potential of agro forestry practices in temperate North America. In: Kumar, B. Mohan; Nair PKR, editors. C sequestration potential of agro forestry systems: opportunities and challenges. 1st ed. Advances in Agro forestry. 2011. p. 17-42.

7. CAST, (Council for Agricultural Science and Technology). C sequestration and greenhouse gas fluxes in agriculture: Challenges and opportunities. Task force report. 2011;142:106.

8. IPCC, (Intergovernmental Panel on Climate Change). Land use, land use change, and forestry: A special report. Intergovernmental Panel on Climate Change. 2000.

9. Sedjo R, Sohngen B. C sequestration in forests and soils. Annual Review of Resource Economics. 2012;4:127-144.

10. Climate Change 2001: The Scientific Basis. Contribution of the Working Group 1 to the Third Assessment Report of the IPCC. Intergovernmental Panel on Climate Change. Cambridge: Cambridge University Press; 2001.

11. Rao KPC, Verchot LV, Laarman J. Adaptation to climate change through sustainable management and development of agro forestry systems. Journal of SAT Agricultural Research. 2007;4(1):1-30.

12. Schoeneberger MM. Agroforestry: working trees for sequestering $\mathrm{C}$ on agricultural lands. Agro forestry Systems. 2009;75:27-37.

13. Nair PKR, Nair VD, Kumar BM. C sequestration in agro forestry systems. Adv Agron. 2010;108:237-307.

14. Nair PKR, Nair VD. Carbon storage in North American agro forestry systems. In: Kimble J, Heath LS, Birdsey RA, editors. The Potential of U.S. Forest Soils to Sequester C and Mitigate the Greenhouse Effect. Boca Raton, FL: CRC Press LLC; 2003. p. 333-346.

15. Eagle AJ, Henry LR, Olander LP, et al. Greenhouse gas mitigation potential of agricultural land management in the United States. $A$ Synthesis of the Literature. 3rd ed. Duke University; 2012.

16. Falkowsky P, Scholes RJ, Boyle E, et al. The global C cycle: A test of our knowledge of the Earth as a system. Science. 2000;290(13):291-296.

17. Annex II. Glossary of terms. Geneva: IPCC; 2014.

18. Sabine CL, Heimann M, Artaxo P, et al. Current status and past trends of the global C cycle. In: Field CB, Raupach MR, editors. The global C cycle: Integrating humans, climate, and the natural world. Washington, DC: Island Press; 2004. p. 17-44.

19. Fourth Assessment Report, Climate Change 2007: Synthesis Report. Geneva: IPCC; 2007. 104 p.

20. Schuur EAG, Bockheim J, Canadell JG, et al. Vulnerability of permafrost $\mathrm{C}$ to climate change: Implications for the global $\mathrm{C}$ cycle. BioScience. 2008;58(8):708-714.

21. Houghton RA. Balancing the Global C Budget. Annual Review of Earth and Planetary Sciences. 2007;35:313-347.
22. Emissions scenarios: A special report of working group III of the intergovernmental panel on climate change. Cambridge: Cambridge University Press; Intergovernmental Panel on Climate Change. 2000.

23. Food and Agriculture Organization of the United Nations. The C sequestration potential in agricultural soils. FAO. 2008.

24. National Oceanic and Atmospheric Administration. Trends in atmospheric carbon dioxide. NOAA. 2015.

25. Dukes J. Will the increasing atmospheric $\mathrm{CO}_{2}$ concentration affect the success of invasive species? In: Mooney HA, Hobbs RJ, editors. Invasive Species in a Changing World. Washington: Island Press; 2000.

26. Field CB, Boesch DF, Stuart F, et al. Ecological impacts of climate change. 2008.

27. Polle A, McKee I, Blaschke L. Altered physiological and growth responses to elevated $\mathrm{CO}_{2}$ in offspring from holm oak (Quercus ilex L.) mother trees with lifetime exposure to naturally elevated $\left[\mathrm{CO}_{2}\right]$. Plant, Cell and Environment. 2001;24:1075-1083.

28. Usami T, Lee J, Oikawa T. Interactive effects of increased temperature and $\mathrm{CO}_{2}$ on the growth of Quercus myrsinaefolia saplings. Plant, Cell and Environment. 2001;24(10):1007-1019.

29. Stiling P, Moon D, Hymus G, et al. Differential effects of elevated $\mathrm{CO}_{2}$ on acorn density, weight, germination, and predation among three oak species in a scrub-oak forest. Global Change Biol. 2004;10(2):228-232.

30. Ainsworth EA, Long SP. What have we learned from 15years of freeair $\mathrm{CO}_{2}$ enrichment (FACE)? A meta-analytic review of the responses of photosynthesis, canopy properties and plant production to rising $\mathrm{CO}_{2}$. New Phytol. 2005;165:351-371.

31. Norby RJ, DeLucia EH, Gielen B, et al. Forest response to elevated CO is conserved across a broad range of productivity. Proc Natl Acad Sci USA. 2005;102(50):18052-18056.

32. Huang JG, Bergeron Y, Denneler B, et al. Response of forest trees to increased atmospheric $\mathrm{CO}_{2}$ Critical Reviews in Plant Sciences. 2007;26(5-6):265-283.

33. Wang XZ. Effects of species richness and elevated carbon dioxide on biomass accumulation: a synthesis using meta-analysis. Oecologia. 2007;152(4):595-605.

34. Lindroth RL, Kiney KK, Platz CL. Responses of deciduous trees to elevated atmospheric co2: productivity, phyto-chemistry, and insect performance. Ecology. 1993;74(3):763-777.

35. Scheffer M, Brovkin V, Cox PM. Positive feedback between global warming and atmospheric $\mathrm{CO} 2$ concentration inferred from past climate change. Geophy Res Lett. 2006;33:L10702.

36. Torn MS, Harte J. Missing feedbacks, asymmetric uncertainties, and the underestimation of future warming. Geophy Res Lett. 2006;33:L10703.

37. Jacoby HD, Janetos AC, Birdsey RJ, et al. Ch. 27: Mitigation. Climate Change Impacts in the United States. The Third National Climate Assessment. In: Melillo JM, Terese TC, Richmond, editors. US: Global Change Research Program. 2014:648-669.

38. National Climate Assessment. Climate Change Impacts in the United States: Mitigation. NCA. 2014.

39. Lal R. Soil C sequestration impacts on global climate change and food security. Science. 2004;304:1623-1627.

40. Meyer M, Tyrchniewicz A. Offsetting $\mathrm{CO}_{2}$ emissions: Tree planting on the prairies. International Institute for Sustainable Development. 1996:1-52.

41. Follett RF. Soil management concepts and $\mathrm{C}$ sequestration in cropland soils. Soil Tillage Res. 2001;61(1-2):77-92.

42. Burras L, Cheng HH, Kimble JM, et al. C Sequestration: Position of the Soil Science Society of America. 2001. 
43. Brandle JR, Wardle TD, Bratton GF. Opportunities to increase tree planting in shelterbelts and the potential impacts on $\mathrm{C}$ storage and conservation. In: Sampson RN, Dwight H, editors. Forests and Global Change. Opportunities for Increasing Forest Cover. Washington: American Forests; 1992:157-176.

44. Albrecht A, Kandji TS. C sequestration in tropical agro forestry systems. Agriculture, Ecosystems \& Environment. 2003;99:15-27.

45. Palm CA, van Noordwijk M, Woomer PL, et al. C losses and sequestration following land use change in the humid tropics. Alternatives to Slash and Burn: The Search for Alternatives. In: Palm CA, Vosti SA, Sanchez PA, editors. New York: Columbia University Press; 2005.

46. Jose S, Gold MA, Garrett HE. The future of temperate agro forestry in the United States. In: Agro forestry in the United States. 2012.

47. High C, Neeraj G. Avoided Emissions from the Antrim Wind Project. 2011.

48. Draucker L. Do We Need a Standard to Calculate "Avoided Emissions"? 2013.

49. CDP, (Carbon Disclosure Project) s.f. Glossary of terms.

50. DeWalle DR, Heisler GM. Use of windbreaks for home energy conservation. Agriculture Ecosystems Environment. 1988;22:243-260.

51. Global Carbon Project. Carbon reductions and offsets. In: Coulter L, Canadell JG, Dhakal S, editors. Earth System Science Partnership Report No. 5. Global Carbon Project Report No. 6, Canberra; 2008.

52. Kort J, Turnock R. Annual accumulation in agro forestry plantations. 1998.

53. Mattingly GE, Harrje DT, Heisler GM. The effectiveness of an evergreen windbreak for reducing residential energy consumption. ASHRAE Trans. $1979 ; 85(2): 428-443$

54. Akbari H, Kurn DM, Bretz SE, et al. Peak power and cooling energy savings of shade trees. Energy and Buildings. 1997;25(2):139-148.

55. Kort J, Turnock R. C reservoir and biomass in Canadian prairie shelterbelts. Agro forestry Systems. 1999;44:175-189.

56. Barker T, Bashmakov I, Bernstein L, et al. Technical Summary. In Climate Change 2007: Mitigation. Contribution of Working Group III to the Fourth Assessment Report of the IPCC. In: Metz B, Davidson OR, Bosch PR, editors. Cambridge: Cambridge University Press; 2007.

57. Johnson JMF, Franzluebbers AJ, Weyers SL, et al. Agricultura opportunities to mitigate greenhouse gas emissions. Environ Pollut. 2007;150(1):107-124.

58. Tinker PB, Ingram J, Struwe SI. Effects of Slash-And-Burn Agriculture and Deforestation on Climate Change. Agriculture, Ecosystems and Environment. 1995;58:13-22.

59. Snyder CS, Bruulsema TW, Jensen TL, et al. Review of greenhouse gas emissions from crop production systems and fertilizer management effects. Agriculture, Ecosystems and Environment. 2009;133(3-4):247266.

60. Bouwman AF. Land use related sources of greenhouse gases: present emissions and possible future trends. Land use policy. 1990;7:154-164.

61. Pitesky ME, Stackhouse KR. Clearing the air: Livestock's contribution to climate change. Advances in Agronomy. 2009;103:1-40.

62. Desjardins RL. The impact of agriculture on climate change. Ottawa: Agriculture and Agri-Food Canada; 2010.

63. Pretty J, Ball A. Agricultural Influences on C Emissions and Sequestration: A Review of Evidence and the Emerging Trading Options. Centre for Environment and Society Occasional Paper 2001-03. UK: University of Essex; 2001. 30 p.
64. Mann LK. Changes in soil C storage after cultivation. Soil Sci. 1986;142(5):279-288.

65. Davidson EA, Ackerman IL. Changes in soil C inventories following cultivation of previously untilled soils. Biogeochemistry. 1993;20(3):161-193.

66. Paustian K, Robertson GP, Elliott ET. Management impacts on C storage and gas fluxes $\left(\mathrm{CO}_{2}, \mathrm{CH}_{4}\right)$ in mid-latitude cropland and grassland ecosystems. In: Lal R, Kimble J, Levine E, editors. Soil Management and Greenhouse Effect, Advances in Soil Science. Boca Raton, FL: CRC Press; 1995. p. 69-84.

67. Buyanovsky GA, Wagner GH. C cycling in cultivated land and its global significance. Global Change Biol. 1998;4:131-141.

68. Freibauer A, Rounsevell MDA, Smith $\mathrm{P}$, et al. C sequestration in the agricultural soils of Europe. Geoderma. 2004;122(1):1-23.

69. Smith P, Martino D, Cai Z, et al. Greenhouse gas mitigation in agriculture Philos Trans R Soc Lond B Biol Sci. 2008;363(1492):789-813.

70. Schlesinger WH. C sequestration in soils. Science. 1999;284(5423):2095.

71. Post MW. Impact of soil restoration, management and land-use history in forest-soil carbon. In: the potential of U.S. forest soils to sequester carbon and mitigate the greenhouse effect. 2002. 448 p.

72. Trumbore SE, Czimczik CI. An uncertain future for soil C. Science. 2008;321(5895):1455-1456.

73. Morris SJ, Conant R, Mellor N, et al. Controls on Soil C Sequestration and Dynamics: Lessons from Land-use Change. J Nematol. 2010;42(1):7883.

74. Harvey CA, Chacon M, Donatti C, et al. Climate-smart landscapes: opportunities and challenges for integrating adaptation and mitigation in tropical agriculture. Conservation Letters. 2013:7(2):77-90.

75. The future of food and farming: challenges and choices for global sustainability. Final Project Report. London: The Government Office for Science; Foresight. 2011.

76. Beddington JR, Asaduzzaman M, Clark ME, et al. The role for scientists in tackling food insecurity and climate change. Agriculture and Food Security. 2012;1:10.

77. The Case for climate-smart agriculture, module 1 and 2. CSA. 2014.

78. Delgado JA, Groffman PM, Nearing MA, et al. Journal of soil and water conservation. 2011;66(4):118-129.

79. Garrity DP, Akinnifesi FK, Ajayi OC, et al. Evergreen Agriculture: a robust approach to sustainable food security in Africa. Food Security. 2010;2:197-214.

80. Lundgren BO, Raintree JB. Sustained agroforestry. In: Nestel B, editor. Agricultural Research for Development: Potentials and Challenges in Asia. ISNAR, The Hague, the Netherlands; 1982. p. 37-49.

81. Kursten E. Fuel wood production in agroforestry systems for sustainable land use and $\mathrm{CO}_{2}$ mitigation. Ecological Engineering. 2000;16:S69-S72.

82. Verchot LV, Noordwijk MV, Kandji S, et al. Climate change: linking adaptation and mitigation through agroforestry. Mitigation and adaptation strategies for global change. 2007;12(5):901-918.

83. Schoeneberger MM, Bentrup G, de Gooijer H, et al. Branching out: Agroforestry as a climate change mitigation and adaptation tool for agriculture. Journal of Soil and Water Conservation. 2012;67(5):128A-136A.

84. Watson RT, Noble IR, Bolin B, et al. Land use, land-use change, and forestry. A special report of the Inter governmental Panel on Climate Change (IPCC). Cambridge: Cambridge University Press; 2000. 375 p. 
85. Smith P, Martino D, Cai Z, et al. Greenhouse gas mitigation in agriculture. Philosophical Transactions of the Royal Society. 2007.

86. Nair PKR, Nair VD, Kumar BM, et al. Soil C sequestration in tropical agro forestry systems: a feasibility appraisal. Environmental Science and Policy. 2009;12(8):1099-1111.

87. Morgan JA, Follett RF, Allen LH, et al. C sequestration in agricultura land of the United States. J Soil Water Conserve. 2010;65(1):6A-13A.

88. Nair PKR, Kumar B, Nair VD. Agro forestry as a strategy for C sequestration. J Plant Nutr Soil Sci. 2009;172:10-23.

89. Lal R, Kimble JM, Follett RF, et al. The potential of US croplands to sequester $\mathrm{C}$ and mitigate the greenhouse effect. Chelsea MI: Ann CCR Press; 1998. 144 p.

90. Franzluebbers AJ. Soil organic C sequestration with conservation agriculture in the southeastern. USA: Potential and limitations. 2010

91. Montagnini F, Nair P. C sequestration: an underexploited environmental benefit of agroforestry systems. Agroforestry Systems. 2004:61-62.

92. Makundi WR, Sathaye JA. GHG mitigation potential and cost in tropica forestry-relative role for agro forestry. Environment, Development and Sustainability. 2004;6(1):235-260.

93. Gold MA, Garret HE. Agro forestry nomenclature, concepts, and practices. In: North American agro forestry an integrated science and practice. 2009. p. 45-55.

94. Murthy IK, Gupta M, Tomar S, et al. C sequestration potential of agro forestry systems in India. J Earth Sci Climate Change 2013;4:131.

95. Poch TJ, Simonetti JA. Ecosystem services in human-dominated landscapes: insectivory in agro forestry systems. Agro forest Syst. 2013;87:871-879.

96. Gordon AM, Thevathasan NV, Nair PKR. An agro-ecological foundation for temperate agro forestry. In: North American agro forestry an integrated science and practice. 2009. p. 25-41.

97. Dixon RK. Agroforestry systems: sources or sinks of greenhouse gases? Agro forestry Systems. 1995.

98. Kumar P, Singh RP, Singh AK, et al. Quantification and distribution of agro forestry systems and practices at global level. Hort Flora Research Spectrum. 2014;3(1):1-6.

99. MIT (Massachusetts Institute of Technology). C sequestration: capture and storage of C dioxide from Earth's atmosphere. 2013

100. Lal R, Bruce JP. The potential of world cropland to sequester carbon and mitigate the greenhouse effect. Environmental Science \& Policy. 1999;2:177-185.

101. Jose S. Agroforestry for ecosystem services and environmental benefits: an overview. Agro forestry Systems. 2009;76:1-10.

102. Newaj R, Dhyani SK. Agro forestry for C sequestration: Scope and present status. Indian Journal of Agro forestry. 2008;10:1-9.

103. Schroeder P. Agroforestry systems: integrated land use to store and conserve C. Climate Research. 1993;3:53-60.

104. Albrecht A, Kandji S, Verchot L. C sequestration in tropical agroforestry systems. World Agroforestry Centre (ICRAF). 2003. 7 p.

105. Sauer TJ, Cambardella CA, Brandle RJ. Soil C and tree litter dynamics in a red cedar-scotch pine shelterbelt. Agro forest Syst. 2007;71(3):163-174.

106. Nair PKR. C sequestration studies in agro forestry systems: a realitycheck. Agro forest Syst. 2011;86:243-253.

107. Chikowo R, Mapfumo P, Nyamugafata P, et al. Mineral N dynamics, leaching and nitrous oxide losses under maize following two-year improved fallows on a sandy loam soil in Zimbabwe. Plant Soil. 2004;25(1-2):315-330.
108. Kandji ST, Verchot LV, Mackensen J, et al. Opportunities for linking climate change adaptation and mitigation through agro forestry systems. In: Garrity DP, Okono A, Grayson M, editors. World Agroforestry into the Future. Nairobi: World Agro forestry Centre (ICRAF); 2006:113-121.

109. Nair PKR. Agro forestry systems and environmental quality: Introduction. J Enviro Qual. 2011;40(3):784-790.

110. Bergeron M, Lacombe S, Bradley RL, et al. Reduced soil nutrient leaching following the establishment of tree-based intercropping systems in eastern Canada. Agro forestry Systems. 2011;83:321-330.

111. Wenger S. A review of the scientific literature on riparian buffer width, extent, and vegetation. FAO. 1999.

112. Falloon PD, Smith P, Powlson D. C sequestration in UK arable soils: the case for field margins. Soil Use Management. 2004;20:240-247.

113. Udawatta RP, Krstansky JJ, Henderson GS, et al. Agro forestry Practices, Runoff, and Nutrient Loss: A Paired Watershed Comparison. J Environ Qual. 2002;31:1214-1225.

114. Berndes G, Fredrikson F, Borjesson P. Cadmium accumulation and Salix based phyto-extraction on arable land in Sweden. Agriculture, Ecosystems and Environment. 2004;103:207-223.

115. Börjesson P, Berndes G. The prospects for willow plantations for wastewater treatment in Sweden. Biomass and Bioenergy. 2006;30(5):428-438

116. Perry $\mathrm{CH}$, Woodhall CW, Liknes GC, et al. Filling the gap: Improving the estimates of working tree resources in agricultural lands. Agro forestry Systems. 2009;75(1):91-101.

117. Sauer T. The Dust Bowl's Prairie States Forestry Project: Model for an Effective Global Climate Change strategy? 2007.

118. Howlett DS, Mosquera-Losada MR, Nair PKR, et al. Soil C storage in silvo pastoral systems and a treeless pasture in northwestern Spain. $J$ Environ Qual. 2011;40(3):825-832.

119. Hernandez-Ramirez G, Sauer TJ, Cambardella CA. Carbon sources and dynamics in afforested and cultivated cornbelt soils. Soil Science Society American Journal. 2011;75:216-225.

120. USDA, U.S. Department of Agriculture. Agro forestry. 2013.

121. Paustian K, Andrén O, Janzen HH, et al. Agricultural soils as a sink to mitigate $\mathrm{CO}_{2}$ emissions. Soil Use \& Management. 1997;13(S4):229-224.

122. Takimoto A. C sequestration potential of agroforestry systems in the West African Sahel: an assessment of biological and socioeconomic feasibility. Ph.D. Thesis Dissertation at University of Florida; 2007. 184 p.

123. Antle JM, Stoorvogel JJ, Valdivia RO. Assessing the economic impacts of agricultural $\mathrm{C}$ sequestration: Terraces and agro forestry in the Peruvian Andes. Agriculture, Ecosystems and Environment. 2007;122:435-445.

124. Brandle JR, Hodges L, Tyndall J, et al. Windbreak practices. In: Garrett HE, editor. North American Agro forestry; an integrated science and practice. 2nd ed. Madison: American Society of Agronomy; 2009. 379 p.

125. Buck L, Lassoie J, Fernandes E. Agro forestry in sustainable agricultural systems. Boca Raton: CRC Press; 1999.

126. Rosenberg NJ. Microclimate: the biological environment. New York: John Wiley \& Sons; 1974

127. Skidmore EL. Wind erosion control. Climatic Change. 1986;9:209-218.

128. Johnson RJ, Beck MM, Brandle JR. Windbreaks and wildlife. 2006.

129. Rhodes T. Windbreaks for wildlife. 2012.

130. Tyndall J, Colletti J. Mitigating swine odor with strategically designed shelterbelt systems: a review. Agro forest Syst. 2007;69:45-65.

131. Caborn JM. Shelterbelts and microclimate. Forestry Commission, Bulletin No. 29. 1957;3(4):135. 
132. USDA Natural Resource Conservation Service (USDA-NRCS) Conservation practices that save: Windbreaks/Shelterbelts. 2006.

133. Moyer RL. Shelterbelt benefit to home heating cost. Transactions of the ASAE. 1999;33(6):3-10.

134. McPherson EG. In Chicago's urban forest ecosystem: results of the Chicago urban forest climate project. Gen. Tech. Rep, NE-186, Radnor, PA: U.S. Department of Agriculture, Forest Service. Northeastern Forest Experiment Station. 1994. 210 p.

135. Tabler RD, Furnish RP. Benefits and costs of snow fences and Wyoming Interstate 80, Transport. Washington D.C: National Academy of Sciences and National Research Council, Transportation Research Board. 1982;860:13-20.

136. Peterson CT, Schmidt RA. Outdoor scale modeling of shrub barriers in snow drifting. Agricultural and Forest Meteorology. 1984;31:167-181.

137. Shaw DL. The design and use of living snow fences in North America Agr Ecosyst Environ. 1988;22-23:351-362.

138. Schmidt RA, Jairell RL, Tabler RD. Snow drifts and the aerodynamic drag on scaled model-shelterbelt. 62th Western Snow Conference, New Mexico; 1994. p. 167-170.

139. Scholten H. Snow distribution on crop fields. Agriculture, Ecosystems and Environment. 1988;22-23:363-380.

140. Robert L, Jairell RL, Tabler RD. Model studies of snowdrifts formed by livestock shelters and pond embankments. 62th Western Snow Conference. New Mexico; 1994. p. 18-21.

141. Van Eimern J, Karscho R, Razumova LA, et al. Windbreaks and shelterbelts Geneva: World Meteorological Organization; 1964;188:159-188.

142. Grace J. Plant response to wind. London, New York: Academic Press 1977. $204 \mathrm{p}$

143. Brandle JR, Hintz DL, Sturrock JW. Windbreak Technology. Amsterdam: Elsevier Science Publishers; 1988. 598 p.

144. Sun D, Dickinson GR. Wind Effect on windbreak establishment in Northern Australia. Tree Planter's Notes. 1994;45(2):72-75.

145. Burke S. Windbreaks. Port Melbourne: Inkata Press; 1998. 128 p.

146. CSIRO, (Commonwealth Scientific and Industrial Research Organization). National windbreaks program: current research on farm trees. 2002;42(6):649-900.

147. Droze WH. Trees, prairies, and people tree planting in the plains states. Denton: Texas Woman's University Press; 1977. 313 p.

148. USDA National Agroforestry Center (USDA-NAC). C: Inside Agroforestry. 2000.

149. Dixon J, Gulliver A, Gibbon D, et al. Farming systems and poverty. Improving Farmers' Livelihoods in a Changing World. Rome, Washington: FAO \& World Bank; 2001.

150. Gliessman SR. Agro ecology: The ecology of sustainable food systems. 2nd ed. Boca Raton: CRC Press/Taylor \& Francis; 2006. 408 p.

151. Behera UK, Sharma AR. Modern concepts of agriculture: farming systems. Indian Agricultural Research Institute; 2007.

152. Francis CA, Porter P. Ecology in sustainable agriculture practices and systems', critical reviews. Plant Sciences. 2011;30:(1-2):64-73.

153. Rhana SS, Chopra P. Integrated Farming System. Department of Agronomy, College of Agriculture, CSK Himachal Pradesh Krishi Vishvavidyalaya, Palampur; 2013. 90 p.

154. Jose S, Gillespie AR, Pallardy SG. Interspecific interactions in temperate agro forestry. Agro forestry Systems. 2004;61:237-255.
155. Altieri MA. Agro-ecology: principles and strategies for designing sustainable farming systems. 1995.

156. Kraten SL. A preliminary examination of the economic performance and energy intensiveness of organic and conventional small. Grain farms in the Northwest. 1979. $316 \mathrm{p}$.

157. Lockeretz W, Shearer G, Kohl DH. Organic farming in the Corn Belt. Science. 1981;211(4482):540-547.

158. Goldstein WA, Young DL. An agronomic and economic comparison of a conventional and a low input cropping system in the Palouse. American Journal of Alternative Agriculture. 1987;2(2):51-56.

159. Weilgart-Patten AG. Comparison of nitrogen and phosphorus fluxes on an organic and conventional farm. Pullman: MSc Thesis, Washington State University; 1982.

160. Pimentel D, Berardi G, Fast S. Energy efficiencies of farming: wheat, corn, and potatoes organically. Organic farming: current technology and its role in a sustainable agriculture. In: Bezdicek DF, editors. American Society of Agronomy. Madison, Wisconsin; 1984. p. 151-161.

161. Bolton H, Elliott LF, Papendick RI, et al. Soil microbial biomass and selected soil enzyme activities: Effect of fertilization and cropping practices. Soil Biol. Biochem. 1985;17(3):297-302.

162. Reganold JP, Elliott LF, Unger YL. Long term effects of organic and conventional farming on soil erosion. Nature. 1987;330(6146):370-372.

163. Reganold JP. Comparison of soil properties as influenced by organic and conventional farming systems. American Journal of Alternative Agriculture. 1988;3(4):144-155.

164. Wells T, Chan KY, Cornish PE. Impact of different conventional and alternative farming systems on soil quality. Agriculture, Ecosystems and Environment. 2000;80:47-60.

165. Hepperly P, Douds, Seidel R. The Rodale farming system trial 1981 2005: long term analysis of organic and conventional maize and soybean cropping systems. In: Raupp J, Pekrun C, Oltmanns M, editors. Longterm field experiments in organic farming. Bonn: International Society of Organic Agricultural Research (ISOFAR). 2006. p. 15-32.

166. Fliessbach A, Oberholzer HR, Gunst L, et al. Soil organic matter and biological soil quality indicators after 21 years of organic and conventiona farming. Agriculture, Ecosystems \& Environment. 2007;118:273-284.

167. Teasdale JR, Coffman CB, Mangum RW. Potential long term benefits of no-tillage and organic cropping systems for grain production and soil improvement. Agronomy Journal. 2007;99(5):1297-1305.

168. Küstermann B, Kainz M, Hülsbergen KJ. Modeling C cycles and estimation of greenhouse gas emissions from organic and conventional farming systems. Renewable Agriculture and Food Systems. 2008;23(1):38-52.

169. USDA National agricultural Statistics Service (USDA- NASS). Crops production 2014. Summary. 2014.

170. Frye WW. Energy requirements in no tillage. In: Phillips RE, Phillips SH, editors. No-tillage Agricultural Principles and Practices. Van Nostrand Reinhold; 1984. p. 127-151.

171. Cole CV, Duxbury J, Freney J, et al. Global estimates of potential mitigation of greenhouse gas emissions by agriculture. Nutrient Cycling in Agro ecosystems. 1997;49(1-3):221-228.

172. Chianese DS, Rotz CA, Richard TL. Simulation of C dioxide emissions from dairy farms to assess greenhouse gas reduction strategies. Trans ASABE. 2009;52(4):1301-1312.

173. Denef K, Paustian K, Archibeque S, et al. Report of greenhouse gas accounting tools for agriculture and forestry sectors. Interim report to USDA, under Contract GS23F8182H. 2012 
174. Young A, Menz KM, Muraya P, et al. SCUAF $\square$ Version 4: A Model to estimate soil changes under agriculture, agroforestry and forestry. ACIAR, Canberra, Australia; Australian Centre for International Agricultural Research. 1998.49 p.

175. Paustian K, Schuler J, K Killian, et al. COMET2.0 - Decision support system for agricultural greenhouse gas accounting. In managing agricultural greenhouse gases: Coordinated agricultural research. In: MA Liebig, AJ Franzluebbers, RF Follett, editors. Through GRACE net to address our changing climate. San Diego, CA: Academic Press; 2012.

176. Casarim FM, Harris NL, Brown S. USAID Forest C Calculator: Data and Equations for the Agro forestry Tool. Win rock International. 2010.

177. Rotz CA, Corson MS, Chianese DS, et al. The integrated farm system model, reference manual, version 3.5. Pasture Systems and Watershed Management Research Unit Agricultural Research Service. USDA. 2012. $191 \mathrm{p}$.

178. USDA Natural Resource Conservation Service (USDA-NRCS). Comet Farm. 2012.

179. Krobel R, Janzen KA, Beauchemin KA, et al. A proposed approach to estimate and reduce the environmental impact from whole farms. Act agriculture Scand Section A. 2012;62(4):225-232.

180. Udawatta RP, Godsey LD. Agro forestry comes of age: putting science into practice. Agro forest Syst. 2010;79:1-4.

181. Nair PKR. Agro forestry: Trees in support of sustainable agriculture. In: Hillel H, Rosenzweig C, Powlson D, editors. Encyclopedia of Soils in the Environment. London: Elsevier; 2004. p. 35-44.

182. Zhou X, Schoeneberger MM, Brandle JR, et al. Analyzing the Uncertainties in use of forest-derived biomass equations for open-grown trees in agricultural land. For Sci. 2015;60(1):144-161.

183. Jose S, Gordon AM. Ecological knowledge and agro forestry design: an introduction. In: Toward agro forestry design. Advances in Agro forestry. 2008;4:3-9.

184. Perry $\mathrm{CH}$, Woodall $\mathrm{CW}$, Schoeneberger MM. Inventorying trees in agricultural landscapes: toward an accounting of working trees. UNL Faculty Publications; 2005;10:12

185. Czerepowicz L, Case BS, Doscher C. Using satellite image data to estimate aboveground shelterbelt carbon stocks across an agricultural landscape. Agric Ecosyst Environ. 2012;156:142-150.

186. Zhou XH, Brandle JR, Awada TN, et al. The use of forest-derived specific gravity for the conversion of volume to biomass for open-grown trees on agricultural land. Biomass and Bioenergy. 2011;35:1721-1731.

187. Takimoto A, Nair PKR, Nair VD. C stock and sequestration potential of traditional and improved agro forestry systems in the West African Sahel. Agri Eco Environ. 2008.

188. Peichl M, Thevathasan NV, Gordon AM, et al. C sequestration potentials in temperate tree-based intercropping systems, southern Ontario, Canada. Agro forest Syst. 2006;66:243-257.

189. Swamy SL, Puri S. Biomass production and C-sequestration of Gmelina arborea in plantation and agro forestry system in India. Agroforest Syst. 2005;64:181-195.

190. Sharrow SH, Ismail S. C and nitrogen storage in agroforests, tree plantations, and pastures in western Oregon. Agro forest Syst. 2004;60:123-130.

191. Duguma B, Gockowski J, Bakala J. Smallholder cacao (Theobroma cacao Linn.) cultivation in agroforestry systems of West and Central Africa: challenges and opportunities. Agro forest Syst. 2001;51:177-188.

192. Beer J, Bonnemann A, Chavez W, et al. Modelling agro forestry systems of cacao (Theobroma cacao) with laurel (Cordia alliodora) or poro
(Erythrina poeppigiana) in Costa Rica, V. Productivity indices, organic material models and sustainability over ten years. Agro forest Syst. 1990;12:229-249.

193. Dossa EL, Fernandes ECM, Reid WS, et al. Above- and belowground biomass, nutrient and $\mathrm{C}$ stocks contrasting an open-grown and a shaded coffee plantation. Agro forest Syst. 2008;72(2):103.

194. Kumar BM, George SJ, Jamaludheen V, et al. Comparison of biomass production, tree allometric and nutrient use efficiency of multipurpose trees grown in wood lot and silvopastoral experiments in Kerala, India. For Ecol Manage. 1998;112:145-163.

195. Kirby KR, Potvin C. Variation in C storage among tree species: Implications for the management of a small-scale $\mathrm{C}$ sink project. For Ecol Manage. 2007;246:208-221.

196. Roshetko M, Delaney M, Hairiah K, et al. C stocks in Indonesian home garden systems: Can small holder systems be targeted for increased C storage? Am J Alt Agr. 2002;17(3):125-137.

197. Parrotta JA. Productivity, nutrient cycling and succession in single and mixed-species stand of Casuarina equisetifolia, Eucalyptus robusta and Leucaena leucocephala in Puerto Rico. For Ecol Manage. 1999;124:4577.

198. Krankina ON, Dixon RK. Forest management options to conserve and sequester terrestrial C in the Russian Federation. World Resource Rev. 1994;6:88-101.

199. Winjum JK, Dixon R, Schroeder PE. Estimating the global potential of forest and agro forestry management practices to sequester C. Water Air Soil Pollut. 1992;64:213-228.

200. Pandey DN. C sequestration in agro forestry systems. Climate Policy. 2002;2(4):367-377.

201. Palma JHN, Graves AR, Bunce RGH, et al. Modeling environmental benefits of silvoarable agro forestry in Europe. Agriculture, Ecosystems and Environment. 2007;119(3-4):320-334.

202. Hazlett PW, Gordon AM, Sibley PK, et al. Stand C stocks and soil C and nitrogen storage for riparian and upland forests of boreal lakes in northeastern Ontario. For Ecol Manag. 2005;219:56-68.

203. Rheinhardt RD, Brinson MM, Meyer GF, et al. Carbon storage of headwater riparian zones in an agricultural landscape. C Balance Manag. 2012;7:4.

204. Bambrick AD, Whalen JK, Bradley RL, et al. Spatial heterogeneity of soil organic $\mathrm{C}$ in tree-based intercropping systems in Quebec and Ontario, Canada. Agro forest Syst. 2010;79:343-353.

205. Clark D, Kim E, Berry C, et al. House characteristics and the effectiveness of energy conservation measures. Journal of the American Planning Association. 1995;61(3):386-395.

206. Heisler GM. Computer simulation for optimizing windbreak placement to save energy for heating and cooling buildings. In: Trees and sustainable development: the third national windbreaks and agro forestry symposium proceedings. Ridge town, Ontario: Ridge town College; 1991.p. 100-104.

207. Huang J, Akbari H, Taha H. The wind shielding and shading effects of trees on residential heating and cooling requirements. ASHRAE Trans. 1990;96:1403-1411.

208. McPherson EG. Using urban forests for energy efficiency and C storage. J Forestry. 1994;92:10.

209. Bates CG. Shelterbelt influences II: the value of shelterbelts in house heating. J For. 1945;43(3):176-196.

210. Woodruff NP. Shelterbelt and surface barrier effects on wind velocities, evaporation, house heating, and snow drifting. Kansas Agric. Exp Stn. Manhattan; 1954. 27 p. 
211. Harrje DT, Buckley CE, Heisler GM. Building energy reductions: windbreak optimization. Journal of the Energy Division. 1981;108(3):143-154.

212. Walk MF, De Walle DR, Heisler GM. Can windbreaks reduce energy use in a mobile home? J Arboric. 1985;11(6):190-195.

213. Sampson RN, Kamp M. Forest and agro forestry opportunities for $C$ sequestration in the Big Sk. the Sampson Group, Inc; 2005. p. 1-24.

214. Wotherspoon A, Thevathasan NV, Gordon AM, et al. C sequestration potential of five tree species in a 25 -year-old temperate tree-based intercropping system in southern Ontario, Canada. Agroforest Syst. 2014;88(4):631-643.

215. Bentrup G. Conservation buffers: design guidelines for buffers, corridors, and greenways. Asheville, NC: Department of Agriculture, Forest Service, Southern Research Station. Gen Tech Rep SRS-109. 2008. 110 p.
216. Climate change mitigation, Contribution of Working Group III to the Fourth Assessment Report of the intergovernmental Panel on Climate Change. Cambridge: Cambridge University Press; 2007. 104 p.

217. Nair PK, Rao MR, Buck LE. New vistas in agro forestry: A compendium for the 1st World Congress of Agro forestry. Advances in Agro forestry. Dordrecht, the Netherlands: Kluwer Academic Publishers; 2004.

218. Shibu J, Sougata B. Agroforestry for biomass production and carbon sequestration: an overview. Agroforestry Systems. 2012;86(2):105-111.

219. U.S. Environmental Protection Agency (USEPA. Inventory of U.S Greenhouse gas emissions and sinks: 1990-2010. 2012. 